\title{
PENDAMPINGAN HAND OVER PASIEN DENGAN METODE KOMUNIKASI SITUATION, BACKGROUND, ASSESMENT, RECOMMENDATION (SBAR) PADA PERAWAT DI RSUD BARRU KABUPATEN BARRU SULAWESI SELATAN
}

\author{
Faisal Faisal ${ }^{1}$, Syahrul Syahrul ${ }^{2}$, Nuurhidayat Jafar ${ }^{3}$ \\ ${ }^{123}$ Universitas Hasanuddin, Makassar \\ E-mail: Faisalrizal911@yahoo.co.id
}

\begin{abstract}
This social service program aims to find out problems in Hospital and to solve the problems by applying problem solving method in nursing management, namely arranging intervention plans, problem identification, and implementation based on the problem found. It was done with the approach of active participants from the group which was taught. The participants involved were both manager nurses and implementer nurses at type C Public Hospital, so that, they are expected to contribute to the patient safety improvement through effective communication. The activities were done in one of the type Chospitals in South Sulawesi Province on September $10^{\text {th }}$ to November $23^{\text {rd }}$, 2018. The results of the activities are the problem was identified by applying patient hand over. It found that the nurses could not implement the hand over optimally based on SPO in the room. The implementation of hand over among shifts is not based on SBAR standard; there was not patient hand over format using SBAR method. The methods used in implementing these activities were socialization, role play, focus group discussion then mentoring activities. Conclusion: these activities were running well and it could improve the knowledge and skills of the nurses in implementing patient had over through SBAR communication method in the internal care room I. It was indicated by the result of accompanying evaluation that the implementation of hand over with S-BAR has been implemented well, with the achievement 83,8\%, while the previous was 66,2\%. So, it increases about $17.6 \%$. It was supported by the commitment of all nurses in the internal care room I, to improve more effective communication.
\end{abstract}

Keywords: Hand Over, SBAR, Nurse, Public Hospital of Barru

\begin{abstract}
Abstrak. Program kegiatan pengabdian pada masyarakat ini bertujuan untuk membantu menemukan masalah yang ada di Rumah Sakit dan menyelesaikan masalah dengan mengaplikasikan metode problem solving dalam manajemen keperawatan, yaitu identifikasi masalah, menyusun rencana intervensi dan implementasi sesuai masalah yang ditemukan, dengan pendekatan partisipasi aktif dari kelompok yang dibina dalam hal ini adalah perawat di Rumah Sakit Umum Daerah tipe C, baik perawat manajer maupun perawat pelaksana, sehingga diharapkan dapat memberikan kontribusi pada upaya meningkatkan keselamatan pasien melalui komunikasi efektif. Kegiatan dilaksanakan di laksanakan di salah satu Rumah Sakit Umum Daerah tipe C Provinsi Sulawesi Selatan pada tanggal 10 Sep - 23 Nov 2018. Hasil yang diperoleh dari pengabdian ini adalah teridentifikasinya masalah dalam penerapan hand over pasien, yaitu perawat belum optimal dalam melaksanakan timbang terima sesuai SPO yang telah ditetapkan di ruangan, belum dilakukan timbang terima antar shif dengan metode SBAR sesuai standar, belum ada format hand over pasien dengan metode SBAR. Metode yang digunakan dalam pelaksanaan kegiatan ini adalah sosialisasi, role play, Focus Grup Discusion kemudian dilanjutkan dengan Kegiatan pendampingan. Kesimpulan: kegiatan ini telah berlangsung dengan baik dan dapat meningkatkan pengetahuan dan skill perawat dalam penerapan hand over pasien dengan metode komunikasi SBAR diruang perawatan interna I hal ini ditunjukkan dari hasil evaluasi pendampingan bahwa pelaksanaan hand over dengan S-BAR sudah terlaksana dengan baik dengan pencapaian 83,8\% yang sebelumnya hanya $66,2 \%$ Jadi ada peningkatan sekitar $17,6 \%$. Hal ini ditunjang oleh komitmen bersama seluruh perawat yang ada di ruang perawatan interna I untuk lebih meningkatkan komunikasi efektif.
\end{abstract}

Kata Kunci: Hand Over, SBAR, Perawat, RSUD Barru

\section{PENDAHULUAN}

Rumah sakit sebagai sebuah industri di bidang kesehatan memiliki karakteristik tersendiri yang serba padat, yaitu padat karya, padat modal, padat teknologi, padat regulasi dan memiliki sumber daya dengan berbagai multidisiplin ilmu, sehingga besar kemungkinan untuk terjadi masalah atau
Kejadian Tidak Diharapkan (KTD) dalam pemberian pelayanan kesehatan (Triwibono, 2013; Pohan, 2015).Untuk menjamin layanan keperawatan sesuai standar, maka perlu dilakukan kegiatan pengendalian mutu (Marquis \& Huston, 2016).

Mutu sebagai salah satu pertimbangan kebijakan utama, cukup mendapat perhatian 
besar dari Instutute of Medicine (IOM) pada tahun 2000 dalam laporannya, 'Err Is Human' terdapat 98.000 kematian di Amerika Serikat yang terjadi setiap tahun akibat medical errors dan tahun 2012 ada sekitar 3 - $16 \%$ Kejadian Tidak Diharapkan (KTD) yang akhirnya memerlukan perpanjangan lama hari rawat atau menimbulkan kecacatan pasien paska perawatan (Jarrar, Rahman, \& Don, 2016). Dalam laporan IOM kedua, Crossing the Quality Chasm, menguraikan sejumlah tujuan meningkatkan mutu dan kinerja sistem layanan kesehatan Amerika Serikat serta beberapa metode untuk mencapai tujuan tersebut (Buchbinder \& Shanks, 2017).

Sedangkan data dari Joint Commussion Data (2017) menyatakan bahwa communication error merupakan salah satu akar penyebab utama kejadian sentinel atau kesalahan medis yang dilaporkan dari tahun 2011 sampai 2013 dan menurut Study 2015 di Amerika Serikat, sekitar $30 \%$ dari semua klaim malpraktik yang mengakibatkan 1.744 kematian dengan kerugian biaya $\$ 1,7$ miliar selama 5 tahun hanya disebabkan karena communication error pada saat memberikan pelayanan (Joint Commussion Data, 2017). Sehingga pada tahun 2004, WHO mencanangkan World Alliance for Patient Safety, program bersama dengan berbagai negara untuk meningkatkan keselamatan pasien di rumah sakit (JCI, 2011).

Dalam Peraturan Menteri Kesehatan (PMK) Nomor 11 tahun 2017 setiap rumah sakit wajib mengupayakan pemenuhan sasaran keselamatan pasien. Sasaran keselamatan pasien meliputi tercapainya ketepatan identifikasi pasien, peningkatan komunikasi yang efektif, peningkatan keamanan obat yang perlu diwaspadai, kepastian tepat-lokasi, tepatprosedur, tepat pasien operasi, pengurangan risiko infeksi terkait pelayanan kesehatan, dan pengurangan risiko pasien jatuh (Permenkes, 2017).

Dari enam unsur sasaran keselamatan pasien yang utama dari layanan asuhan ke pasien adalah komunikasi efektif. Menghindari resiko kesalahan dalam pemberian asuhan keperawatan pasien dan meningkatkan kesinambungan perawat dan pengobatan maka dapat diwujudkan dengan baik melalui komunikasi yang efektif antar perawat, maupun dengan tim kesehatan yang lain (Nursalam, 2015).

Sedangkan Standar Nasional Akreditasi Rumah Sakit (SNARS) 2017 pada Sasaran Keselamatan Pasien(SKP.2.2) mensyaratkan agar rumah sakit menetapkan dan melaksanakan proses komunikasi "Serah Terima" (hand over) dan menyusun cara komunikasi yang efektif, tepat waktu, akurat, lengkap, jelas, dan dapat dipahami penerima (SNARS, 2017). Hand over pasien dirancang sebagai salah satu metode untuk memberikan informasi yang relevan pada tim perawat setiap pergantian shif, sebagai petunjuk praktik memberikan informasi mengenai kondisi terkini pasien, tujuan pengobatan, rencana perawatan serta menentukan prioritas pelayanan yang dilakukan secara tepat waktu, akurat, lengkap, jelas, sehingga dapat dipahami, dan akan mengurangi kesalahan, serta menghasilkan peningkatan keselamatan pasien (Rushton,2010; Santoso, 2018)

Berdasarkan survey awal yang telah dilakukan di RSUD Barru Kab. Barru Provinsi Sulawesi Selatan, salah satu hambatan yang dihadapi dalam menerapkan keselamatan pasien yaitu belum optimalnya komunikasi efektif khususnya hand over pasien pada saat pergantian jaga.

Untuk mengatasi masalah tersebut, maka tim pengabdian masyarakat dari keperawatan Unhas, perlu dilakukan kegiatan sosialisasi hand over, pengadaan buku pedoman, format hand over, Standar Prosedur Operasional (SPO) hand over dengan metode SBAR sebagai panduan bagi perawat di ruangan ketika melaksanakan hand over pasien, serta melakukan pendampingan hand over.

\section{METODE PELAKSANAAN \\ Tempat dan Waktu}

Program pengabdian masyarakat dilakukan di Rumah Sakit Umum Daerah Barru Jl. Lasawedi Kelurahan Coppo, Kecamatan Barru ,Kabupaten Barru Provinsi Sulawesi Selatan pada tanggal 10 September - 23 November 2018.

\section{Sasaran}

Kegiatan pengabdian masyarakat ini melibatkan pihak manajemen RSUD Barru, Tim pokja akreditasi Sasaran Keselamatan Pasien (SKP), Kepala ruangan, ketua tim dan perawat pelaksana.

\section{Metode}

Ada beberapa tahap pelaksanaan pengabdian masyarakat yang dilakukan yaitu:

\section{Tahap Penentuan Masalah}

Tahap penentuan masalah diawali dengan melakukan pengkajian atau pengumpulan data yang dilaksanakan pada tanggal 10 - 20 September 2018 diseluruh ruang perawatan. Metode yang digunakan dalam pengumpulan data yaitu metode wawancara semi terstruktur selama 50-90 menit kepada Plt. KTU, Kepala bidang keperawatan; Kepala seksi asuhan, Etika dan 
profesi keperawatan; Penanggung Jawab Komite Keselamatan Pasien Rumah Sakit(PKPRS) dan 9 orang kepala ruangan rawat inap serta penyebaran kuesioner kepada 30 orang perawat pelaksana.

\section{Tahap Identifikasi dan Prioritas Masalah}

Tahap identifikasi dan prioritas masalah dilakukan pada tanggal 21 September - 02 Oktober 2018. identifikasi masalah dilakukan dengan Focus Group Discussion (FGD). Hasil identifikasi masalah kemudian dilakukan penentuan prioritas masalah dengan melihat 3 aspek utama yaitu dari tingkat kegawatan (Urgency), tingkat mendesak (Seriousness) dan tingkat pertumbuhan (Growth). Penilaian dilakukan dengan menggunakan skala likert 1-5. 1 = sangat $\mathrm{kecil} / \mathrm{rendah}$ pengaruhnya, $2=\mathrm{kecil}$ pengaruhnya, $3=$ sedang/cukup berpengaruh, $4=$ besar/tinggi pengaruhnya, $5=$ sangat besar pengaruhnya.

\section{Tahap Analisis Masalah dan Rencana Kegiatan.}

Analisis masalah dilakukan dengan menggunakan analisis fish bone dan analisis SWOT. Hasil analisis kemudian didiskusikan (FGD) pada tanggal 10 Oktober 2018 Plt. KTU, Kepala bidang keperawatan, Seksi asuhan etika dan profesi keperawatan, Ketua tim pokja akreditasi SKP, Penanggung jawab tim keselamatan pasien, Kepala ruangan, Ketua tim dan Perawat pelaksana untuk melakukan diskusi terkait kegiatan-kegiatan yang dapat dilakukan untuk mengatasi masalah yang telah ditemukan. Adapun kegiatan yang akan dilakukan untuk mengatasi masalah yang telah ditemukan adalah:

1. Penyusunan buku pedoman hand over metode SBAR

2. Penyusunan Standar Prosedur Operasional (SPO) dan Format hand over pasien dengan SBAR

3. Sosialisasi hand over pasien dengan metode komunikasi SBAR

4. Pendampingan dan monitoring evaluasi kegiatan

\section{Tahap Persiapan Implementasi}

1. Melakukan diskusi dengan kepala bidang keperawatan, seksi asuhan, etika dan profesi keperawatan dan penganggung jawab sasaran keselamatan pasien terkait rencana pelaksanaan kegiatan sosialisasi dan rencana pengadaan buku pedoman, SPO, format hand over dengan SBAR, dan rencana pelaksanaan kegiatan pendampingan monitoring evaluasi kegiatan di ruang Interna I.
2. Mempersiapkan materi atau bahan bacaan, dokumen-dokumen yang dibutuhkan dalam kegiatan sosialisasi seperti fotocopy materi hand over dengan metode SBAR,kerangka acuan role play, foto copy SPO dan format hand over dengan SBAR

3. Menyusun instrument wawancara setelah kegiatan sosialisasi tentang hand over pasien dengan metode SBAR serta menyusun intrument lembar observasi kegiatan dengan jumlah pertanyaan sebanyak 10 butir terkait penerapan hand over pasien dengan metode SBAR pada saat pergantian shift untuk kegiatan monitoring dan evaluasi.

4. Menyampaikan permohonan kesediaan kepada Direktur RS/ Plt. Kepala Tata Usaha(KTU) untuk membuka kegiatan sosialisasi tentang hand over pasien dengan metode SBAR dan kesediaan kepala bidang keperawatan, penanggung jawab komite keselamatan pasien, dan kepala ruangan interna I untuk mendampingi proses kegiatan monitoring dan evaluasi kegiatan.

5. Konsultasi dan bimbingan kepada supervisor dan co-supervisor

6. Mengidentifikasi nara sumber sesuai bidang keahliannya

7. Mengidentifikasi peserta kegiatan

8. Mengidentifikasi tempat pelaksanaan kegiatan

9. Menyiapkan administrasi persuratan dan perlengkapan

\section{Tahap Pelaksanaan}

1. Kegiatan sosialisasi hand over pasien dengan metode SBAR pada saat pergantian shift dengan pemateri Haeruddin,S.ST dilaksanakan pada tanggal 15 Nov 2018 mulai pukul 13:00 sampai pukul 15:00 dengan jumlah sebanyak 27 peserta. Kemudian dilanjutkan role play diruangan interna I

2. Pencetakan buku pedoman hand over pasien metode SBAR

3. Pendampingan, monitoring dan evaluasi dilaksanakan di Ruang Perawatan Interna I pada tanggal 16-23 Nov 2018

\section{Tahap Evaluasi}

1. Evaluasi penyusunan buku pedoman, SPO dan Format hand over pasien dengan SBAR

2. Evaluasi kegiatan sosialisasi dilakukan dengan wawancara kepada peserta yang telah mengikuti dari awal sampai kegiatan selesai

3. Evaluasi pelaksanaan implementasi di ruangan dengan metode observasi. Sebelum pendampingan dilakukan observasi dan setelah pendampingan dilakukan observasi kembali. 
HASIL DAN PEMBAHASAN

Penyusunan Buku Pedoman Komunikasi Efektif dengan Hand Over Metode SBAR, SPO Handover Antar Shif dan Format Hand Over SBAR

Kegiatan penyusunan buku pedoman, SPO dan format handover dengan SBAR, setelah pencarian literatur maka pada tanggal 22 Okt sampai dengan 26 Okt 2018, kegiatan penyusunan ini konsultasi dengan supervisor lahan, kasie keperawatan dan bekerjasama dengan ketua pokja tim akreditasi SKP (Sasaran Keselamatan Pasien) yaitu dr. Nurkhairaty, M.Kes., Sp.PA dan Fitri,S.ST sebagai anggota tim pokja akreditasi sasaran keselamatan pasien pada bagian Elemen Penilaian SKP.2 yaitu meningkatkan komunikasi efektif. Hasil: buku pedoman ,SPO dan Format sudah ada namun belum dibuatkan kebijakan oleh direktur Rumah Sakit.

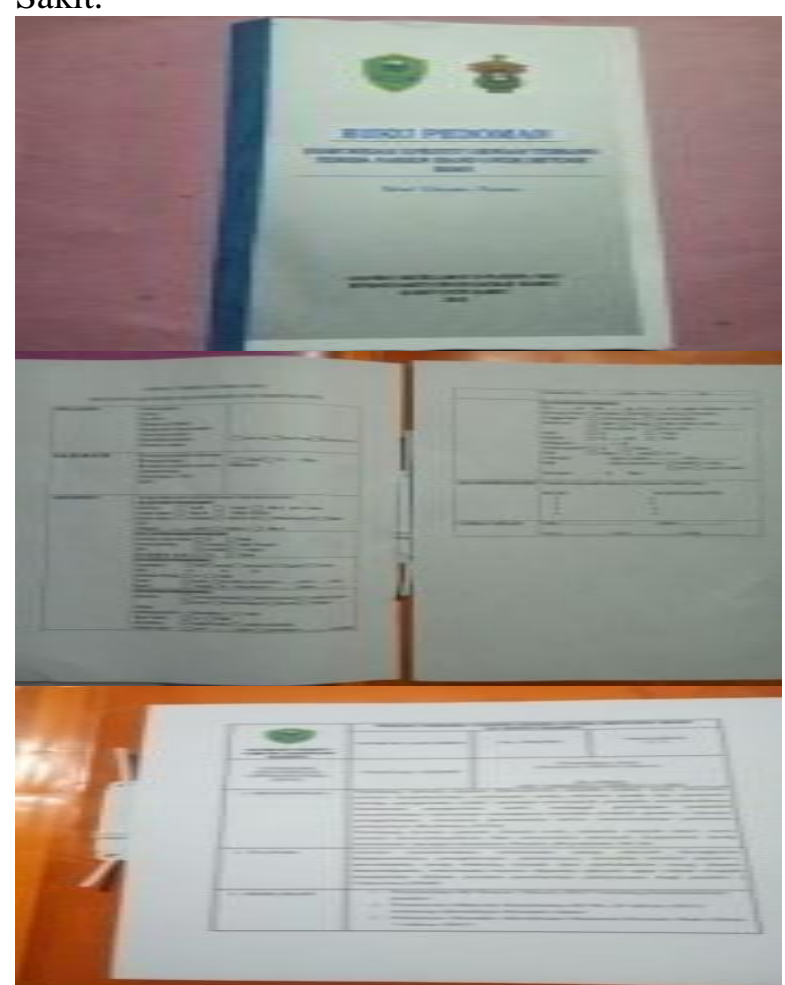

Gambar 1. Buku pedoman, Standar Prosedur Operasional (SPO) hand over dan format hand over dengan SBAR

Kelengkapan dokumen menjadi hal yang penting untuk mendukung berjalannya proses menuju perubahan yang lebih baik. Dalam Standar Akreditasi Nasional Rumah Sakit (SNARS, 2017) dikatakan bahwa beberapa dokumen harus dilengkapi oleh pihak Rumah Sakit dalam menunjang implementasi patient safety.

\section{Sosialisasi Hand Over Pasien Dengan Metode SBAR}

Karakteristik peserta yang mengikuti sosialisasi dapat dilihat pada tabel 1 dibawah ini:

Tabel 1.

Karakteristik responden mengikuti kegiatan sosialisasi di RSUD Barru

$(n=27)$

\begin{tabular}{llcl}
\hline & $\mathbf{n}$ & $\mathbf{( \% )}$ & Mean $\mathbf{\pm}$ SD \\
\hline Laki-laki & 4 & 14.8 & \\
Perempuan & 23 & 85.2 & \\
& & & \\
Ners & 13 & 48.1 & \\
D3 & 14 & 51.9 &
\end{tabular}

\begin{tabular}{cccc} 
& & $29.00 \pm 5.357$ \\
\hline Sosialisasi komunikasi & efektif & dengan \\
handover antar shif & dengan & metode
\end{tabular} SBAR,sekaligus sosialisasi format hand over dan SPO bekerja sama dengan dengan ketua Pokja Tim akreditasi SKP yaitu dr. Nurkhairaty, M,Kes.,Sp.PA dan anggota Tim Pokja akreditasi SKP yang telah dilaksanakan pada hari kamis tanggal 15 November 2018 yang dimulai dari pukul 13:00 - 15:00 ruang pertemuan lantai II RSUD Barru dengan nara sumber Haeruddin, S.ST selaku kepala asuhan,etika dan profesi keperawatan RSUD Barru yang telah bersertifikat dibidang informasi dan komunikasi.

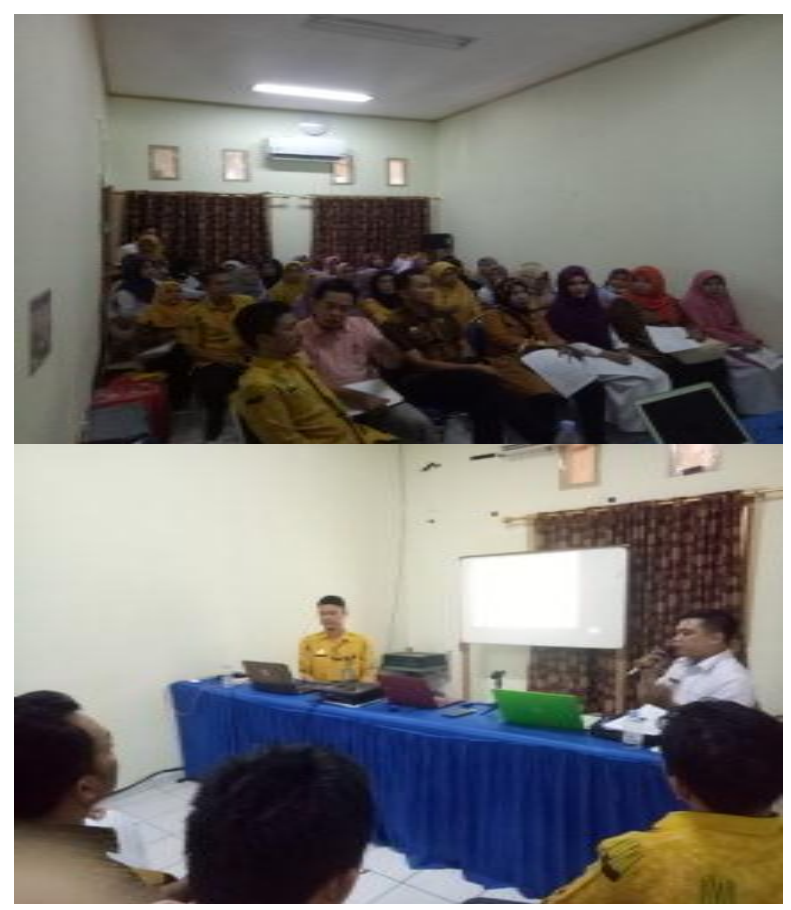

Gambar 2. Kegiatan sosialisasi hand over pasien dengan komunikasi SBAR. 
Setelah kegiatan sosialisasi menurut sekertaris akreditasi pokja Sasaran Keselamatan Pasien selaku Ketua PPNI RSUD Barru mengatakan bahwa 'Timbang terima dengan handover metode SBARsangat bagus dan ini yang seharusnya dijalankan dan dipertahankan karna sebagai pasien jelas informasinya yang di sampaikan oleh perawat sehingga meminimalkan kesalahan informasi"

Kepala ruangan Interna I RSUD Barru mengatakan bahwa 'Sebenarnya timbang terima sering dilakukan oleh teman-teman tapi kali ini jelas karna sudah lengkap tapi pada dasarnya sama hanya metodenya ini SBAR dan kalau diterapkan bagus sekali sebagai salah satu penilaian kinerja perawat untuk mendapatkan reward dan harapan saya agar komunikasi hand over ini dapat berjalan dengan baik dan perlu dukungan dari pihak manajemen ".

Sedangkan menurut salah satu Ketua Tim bahwa 'bagus sekali, lebih jelas karna yang disampaikan terstruktur dari $S, B, A, R$ jadi komunikasi antar sesama teman tidak hanya baca buku laporan saja tapi ....jelas semua kondisinya pasien yang mau disampaikan kepada petugas selanjutnya dan selama ini operan diruangan hanya di ners station".

Dan menurut salah satu perawat pelaksana RSUD Barru mengatakan bahwa "Pemikiran saya selama ini bahwa SBAR khusus untuk komunikasi lewat telpon dokter saja yang didokumentasikan dicatatn integrasi ternyata SBAR bisa di gunakan saat pergantian jaga saat operan pasien diruangan. Bagus karna sudah ada formatnya sisa dicek list saja, baru ada juga diskusinya setelah dari pasien selama ini tidak dilakukan tapi SPO dan buku pedoman yang disosialisasikan belum tersedia diruangan"

Data tersebut menunjukkan bahwa salah satu kebijakan strategi yang dilakukan untuk meningkatkan pemahaman dan kejelasan terhadap hand over pasien dengan SBAR sesuai SPO yang akan dilaksanakan. Sosialisasi penting dilaksanakan secara berkala untuk meningkatkan pemahaman perawat pelaksana sehingga penerapan hand over dapat berjalan dengan baik sehingga pelayanan keperawatan standar sangat membantu perawat untuk mencapai asuhan yang berkualitas (Simamora, 2014). Penelitian yang dilakukan oleh Sari, Suprapti \& Solechan, (2014) yang menyatakan bahwa sosialisasi yang dilakukan oleh pihak Rumah Sakit membantu merubah prilaku perawat dalam memberikan asuhan keperawatan ke arah yang lebih baik.

Pendampingan Penerapan Hand Over Metode SBAR diruang Perawatan Interna I
Pendampingan penerapan hand over metode komunikasi SBAR dilaksanakan diruang perawatan interna I.

Tabel 2.

Karakteristik Responden berdasarkan jenis kelamin, tingkat pendidikan, umur di ruangan interna I RSUD Barru $(\mathbf{n}=13)$

\begin{tabular}{llll}
\hline Kriteria & $\mathbf{n}$ & $\mathbf{( \% )}$ & Mean $\mathbf{\pm}$ SD \\
\hline Laki-laki & 1 & $\mathbf{7 . 7}$ & \\
Perempua & 12 & 92.3 & \\
n & & & \\
& 5 & 38.4 & \\
Ners & 4 & 30.8 & \\
S1 & 4 & 30.8 & \\
D3 & & & $27.31 \pm 4.516$ \\
& & & \\
Umur & & & \\
\hline
\end{tabular}

Pada tabel 2 menunjukkan bahwa perawat diruang perawatan interna I paling banyak adalah perempuan sebanyak 12 (92.3\%) sedangkan perawat laki-laki hanya ada 1 (7.7\%). Dan pendidikan Ners paling banyak sebanyak 5 (38.4\%) sedangkan pendidikan S1 dan D3 masing $4(30.8 \%)$. Sedangkan umur perawat diruang perawatan interna I rata-rata 27.31

Pendampingan ini di awali dengan melaksanakan FGD (Fokus group discussion). Materi yang di bahas adalah tahapan-tahapan dalam pelaksanaan handover dengan metode SBAR sekaligus memberikan contoh secara tertulis yang disampaikan saat handover antar shif ke pasien. Pendampingan ini dilaksanakan pada tanggal 17 November - 23 November 2018 yang dihadiri oleh kepala ruangan, ketua Tim dan perawat pelaksana yang bertugas pada saat itu. Sebelum pendampingan melakukan observasi setiap shift pada tanggal 15 - 17 November 2018 sedangkan evaluasi dilakukan setiap hand over dilakukan observasi sampai pada tanggal 23 November 2018.

Selama proses pendampingan hand over pasien pada perawat diruang interna I, tim pengabdian masyarakat bersama sekretaris pokja akreditasi SKP bersama-sama mengikuti pendampingan dan memonitoring evaluasi penerapan hand over.

Pendampingan menjadi salah salah satu cara yang dapat digunakan untuk menjaga, mempertahankan perawat dan sekaligus meningkatkan ketrampilan serta selanjutnya meningkatkan produktivitas perawat. 


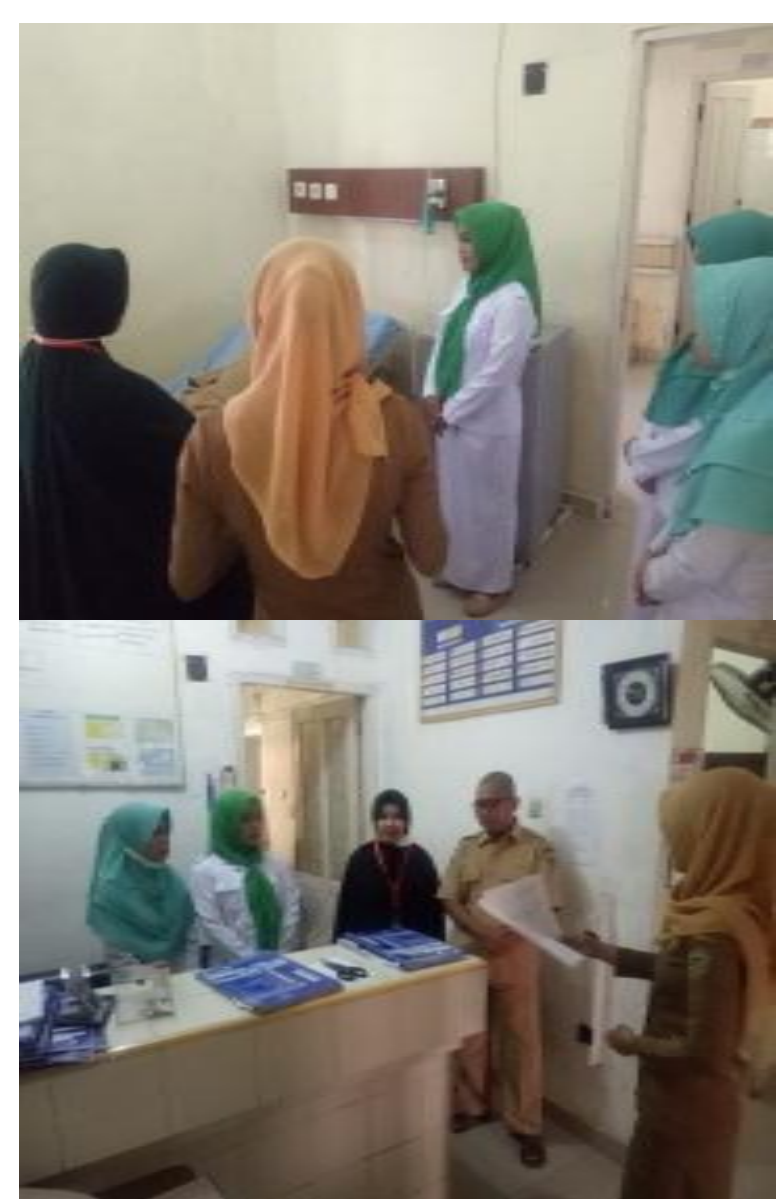

Gambar 3. Pendampingan hand over pasien dengan komunikasi SBAR pada perawat di ruangan interna I RSUD Barru

Pada gambar 3 pendampingan hand over pasien dilakukan oleh perawat interna I dengan hand over dari petugas jaga pagi ke petugas jaga siang yang dilaksanakan diruangan pasien. Setelah itu dilakukan diskusi diruang ners station untuk mendiskusikan hal-hal yang belum dimengerti oleh petugas jaga berikutnya. Perawat ruang perawatan interna I sangat antusias dalam kegiatan ini, terlihat dari aktifnya perawat dalam menanggapi dan bertanya tentang hal-hal yang terkait dengan handover dengan SBAR dan pendampingan selama 7 hari, tim pengabdian masyarakat telah mengikuti, mengarahkan dan memberi masukan dalam melakukan operan tiap hari.

Salah satu kendala yang dihadapi perawat pelaksana pada saat hand over adalah perawat masih sibuk membuka status pasien bolak balik saat operan didepan pasien.

\section{Hasil Observasi Sebelum Pendampingan Dan Setelah Pendampingan Hand Over}

Sebelum pendampingan pada nomor 6 lembar observasi yaitu menjelaskan kondisi pasien dengan metode SBAR hanya 1 perawat yang melakukan, setelah pendampingan terjadi peningkatan menjadi 12 perawat. Untuk point 10 yaitu aspek serah terima pada akhir kegiatan operan jaga dengan menandatangani buku laporan operan jaga tidak mengalami peningkatan yang signifikan dengan skor pre-pendampingan 0 dan skor post-pendampingan 1dikarenakan perawat terlebih dahulu menandatangani buku laporan sebelum dilakukan pertukaran shift. Hal ini dapat dilihat pada tabel 3 .

\begin{tabular}{ccr}
\multicolumn{2}{c}{ Profesionalisme dalam } & pelayanan \\
keperawatan dapat & dicapai & dengan
\end{tabular} mengoptimalkan peran dan fungsi perawat, terutama peran dan fungsi mandiri perawat. Hal ini dapat diwujudkan dengan baik melalui komunikasi yang efektif antarperawat, maupun dengan tim kesehatan yang lain (Nursalam, 2015). Komunikasi efektif merupakan komunikasi yang dilakukan diantara kelompok professional,kelompok profesional kesehatan dengan manajemen, professional dengan pasien dan keluarga, yang dilakukan secara tepat waktu, akurat, lengkap, jelas, sehingga dapat dipahami, dan akan mengurangi kesalahan, serta menghasilkan peningkatan keselamatan pasien ( Santoso, 2018)

Timbang terima pasien (Handover) adalah salah satu bentuk komunikasi perawat dalam melaksanakan asuhan keperawatan pada pasien.Timbang terima pasien dirancang sebagai salah satu metode untuk memberikan informasi yang relevan pada tim perawat setiap pergantian shift, sebagai petunjuk praktik memberikan informasi pergantian shift,sebagai petunjuk praktik memberikan informasi mengenai kondisi terkini pasien, tujuan pengobatan, rencana perawatan serta menentukan prioritas pelayanan (Rushton, 2010).

Tabel 3.

Hasil observasi sebelum pendampingan dan setelah pendampingan pada perawat di ruang perawatan interna I RSUD Barru $(\mathbf{n}=13)$

\begin{tabular}{llrll}
\hline & $\begin{array}{l}\text { Aktivitas } \\
\text { diobservasi }\end{array}$ & yang & $\begin{array}{l}\text { Pr } \\
\text { e }\end{array}$ & Post \\
\hline 1. & $\begin{array}{l}\text { Mempersiapkan } \\
\text { laporan dan status }\end{array}$ & buku & 6 & 11 \\
2. & $\begin{array}{l}\text { Timbang terima di ikuti } \\
\text { oleh perawat yang akan } \\
\text { dinas }\end{array}$ & 13 & 13 \\
3. & $\begin{array}{l}\text { Menjelaskan } \\
\text { seluruh pasien, masalah } \\
\text { keperawatan dan tindakan } \\
\text { yang telah dilakukan }\end{array}$ & & \\
\end{tabular}




\section{Mengucapkan salam $13 \quad 13$ sebelum melakukan overan ke pasien \\ 5. Memperkernalkan perawat $12 \quad 13$} yang akan dinas

6. Menjelaskan kondisi pasien dengan metode $\mathrm{S}=$ kondisi terkini pasien, $\mathrm{B}=$ informasi penting yang berhubungan dengan kondisi pasien, $\mathrm{A}=$ hasil pengkajian kondisi terkini, $\mathrm{R}=$ apa yang perlu dilakukan untuk mengatasi masalah pasien dengan Efektif

7. Memberitahu pasien, perawat yang bertanggungjawab kepada pasien

8. Mengucapkan salam $13 \quad 13$ sebelum meninggalkan pasien

9. Berkumpul untuk diskusi 347 (pre conference)

10 Timbang terima di akhiri $\begin{array}{llll}\text { dengan menandatangani } & 0 & 1\end{array}$ buku laporan

Untuk mengetahui apakah ada perbedaan penerapan hand over secara bermakna maka dapat dilihat pada tabel 4 dibawah ini:

\section{Tabel 4.}

Skor aktivitas hand over pasien sebelum dan sesudah diberikan pendampingan komunikasi SBAR

$\begin{array}{cl}(\mathbf{n}=13) \\ \mathbf{n} & \begin{array}{l}\text { Mean } \\ \text { SD }\end{array} \mathbf{p}^{\mathbf{a}}\end{array}$

\begin{tabular}{lcccc}
\hline Pre pendampingan & 13 & $6.62 \pm$ & & 0.01 \\
& & 0.870 & \\
Post & 13 & & \\
Pendampingan & \multicolumn{3}{c}{$8.38 \quad \pm$} \\
\multicolumn{4}{c}{1.044} \\
\hline a Probability dengan menggunakan uji wilcoxom
\end{tabular}

Pada tabel 4 diatas nilai rata-rata sebelum pendampingan 6,62 atau $66,2 \%$ dan setelah pendampingan penerapan hand over pasien ratarata 8,83 atau $88,3 \%$ dengan demikian terjadi peningkatan sebesar $17,6 \%$. Sedangkan hasil uji wilcoxom dapat disimpulkan secara statistik ada perbedaan penerapan hand over pasien dengan komunikasi SBAR sebelum dan sesudah dilakukan pendampingan. Dari hasil statistik adalah adanya perbedaan hand over pasien dengan SBAR sebelum dan sesudah pendampingan dengan nilai signifikansi $\mathrm{P}=0,01$ $(\mathrm{P}<0,05)$.

Hasil ini sejalan dengan penelitian penelitian Marjani (2015) Terdapat pengaruh yang signifikan mengenai dokumentasi timbang terima pasien dengan metode SBAR terhadap Insiden Keselamatan Pasien di ruangan. komunikasi merupakan bagian penting dalam pelaksanaan pelayanan, komunikasi yang mendukung keselamatan tidak terlepas dari standar dan prosedur komunikasi yang digunakan dan aspek keselamatan yang diinformasikan. Komunikasi yang akurat tentang pasien harus diinformasikan pada saat hand over, kurangnya informasi ataupun tidak tersampaikannya informasi penting terkait kondisi terkini pasien dapat menimbulkan resiko terjadinya kesalahan dan ketidaksinambungan asuhan keperawatan pada pasien.

Jurnal Penelitian Velji et al (2008) tentang Efektifitas Alat Komunikasi SBAR dalam Pengaturan Perawatan di Ruang Rehabilitas mengatakan bahwa komunikasi yang efektif dan kerja sama tim telah diidentifikasikan dalam literature sebagai kunci pendukung dari keselamatan pasien.

Proses komunikasi SBAR terbukti telah menjadi alat komunikasi yang efektif dalam pengaturan perawatan akut untuk tingkatan komunikasi yang urgen, terutama antara dokter dan perawat, namun masih sedikit yang diketahui dari efektifitas dalam pengaturan tentang hal yang lain. Penelitian ini mengevaluasi efektivitas alat SBAR yang digunakan dalam situasi mendesak dan tidak mendesak di ruang rehabilitasi yang melibatkan staf, klinis, pasien dan keluarga. Penelitian ini menunjukkan bahwa penggunaan alat komunikasi SBAR yang disesuaikan kondisinya dapat membantu dalam komunikasi, baik individu dengan tim yang akhirnya dapat mempengaruhi perubahan dalam meningkatkan budaya keselamatan pasien dari tim, sehingga ada dampak positif dan terlihat ada perbaikan pada pelaporan insiden keselamatan.

Menurut Riesenberg (2010) bahwa pelatihan atau pendampingan komunikasi SBAR merupakan salah satu strategi yang dapat digunakan untuk meningkatkan efektifitas operan jaga pasien. Pelatihan ini dilakukan sebagai upaya untuk menghilangkan kesenjangan pengetahuan, sikap dan ketrampilan sebagai komponen utama perilaku, sehingga dapat meningkatkan efektifitas dan mutu hand over pasien pasien. 


\section{SIMPULAN DAN SARAN}

1. Hasil pelaksanaan kegiatan dalam pengabdian ini secara umum memberikan efek positif terhadap perubahan dan peningkatan kualitas mutu pelayanan kesehatan. Kegiatan-kegiatan yang telah dilakukan selama proses pengabdian memberikan perubahan perilaku dan pola pikir terhadap perawat dalam menerapkan hand over pasien dengan SBAR sesuai syarat akreditasi SNARS 2017.

2. Kegiatan dalam pengabdian ini terlaksana dengan baik, adapun hasil evaluasi pelaksanaan hand over dengan SBAR pencapaian rata- rata $83,8 \%$ yang sebelumnya hanya $66,2 \%$ Jadi ada peningkatan sekitar $17,6 \%$.

3. Dari hasil statistik adalah adanya perbedaan pelaksanaan hand over pasien dengan SBAR sebelum dan sesudah pendampingan dengan nilai signifikansi $\mathrm{P}=0,01(\mathrm{P}<0,05)$.

4. Tersedianya buku pedoman hand over, SPO, Format Hand over dan perawat mulai beradaptasi melaksanakan hand over tiap hari dengan komunikasi SBAR.namun belum dibuatkan kebijakan oleh direktur rumah sakit.

Berdasarkan hasil evaluasi dengan cara observasi, wawancara, diskusi / Tanya jawab dengan perawat selama proses penyusunan buku pedoman, SPO , format hand over, proses sosialisasi dan pendampingan maka rekomendasi dan tindak lanjut dari kegiatan pengabdian masyarakat ini adalah sebagai berikut :

1. Buku pedoman hand over, SPO hand over, format hand over yang sudah ada agar dibuatkan kebijakan oleh direktur RSUD Barru sebagai pedoman pelaksanaan hand over pasien dengan metode SBAR ditiap unit perawatan

2. Tim pokja akreditasi SKP bekerja sama dengan pihak manajemen rumah sakit melakukan monitoring evaluasi tiap bulan untuk mengetahui capaian target terkait penerapan hand over metode SBAR sesuai syarat standar akreditasi berdasarkan SNARS meningkatan komunikasi efektif.

3. Perlunya tindak lanjut oleh pihak Rumah Sakit terhadap intervensi yang telah dilakukan tim pengabdian masyarakat keperawatan unhas sehingga pelaksanaannya dapat berkesinambungan

4. Perlunya komitmen bersama antara pihak Rumah Sakit serta seluruh staff keperawatan dalam menunjang pelaksanaan hand over dengan SBAR demi mewujudkan pelayanan keperawatan yang berkualitas demi meningkatkan mutu pelayanan di RSUD Barru.

\section{DAFTAR PUSTAKA}

Adreoli, A., Fancott, C., Velji, K et al . (2010). Using SBAR to Communicate Falls risk and manajement in Inter-profesional Rehabilitation Teams. Journal Healthcare Quarterly. Diunduh dari www.longwoods.com

Buchbinder, S., \& Shanks, N. (2017). Manajemen Pelayanan Kesehatan. Jakarta: EGC.

Calalang, V.H \& Javier.(2010). Standards of effective communication. http://www.bellaonline.com/articles/art4617 0 .asp diakses 24 September 2018

Huber, D. L. (2010). Leadership and Nursing Care Management. (N. O"Brien, Ed.), Saunders Elsevier (4th ed.). Lowa: Sauders Elsevier. https://doi.org/10.1007/s13398014-0173-7.2

Jarrar, M., Rahman, H. A., \& Don, M. S. (2016). Optimizing Quality of Care and Patient Safety in Malaysia: The Current Global Initiatives, Gaps and Suggested Solutions, $8(6)$, $75-85$. https://doi.org/10.5539/gjhs.v8n6p75

Joint Commission International. (2011). Standar Akreditasi Rumah Sakit, Enam Sasaran Keselamatan Pasien. edisi 4

Komisi Akreditasi Rumah Sakit. (2018). Standar Nasional Akreditasi Rumah Sakit(SNARS) (1st ed.). Jakarta: Kementerian Kesehatan RI.

Marjani, F. (2015). Pengaruh Dokumentasi Timbang Terima Pasien dengan Metode SBAR terhadap Insiden Keselamatan Pasien di Ruang Medikal Bedah RS. Panti Waluyo Surakarta. Stikes Kusuma Husada Surakarta, 1-63.

Marquis, B. L., \& Huston, C. J. (2012). Leadership Roles \& Management Functions In Nursing: Theory\& Application (7th ed.). Philadelphia: Lippincott Williams \& Wilkins.

Nur, H. A., \& Santoso, A. (2018). Komunikasi Interprofesional Dalam Peningkatan Keselamatan Pasien: Systematic Review, 1(1).

Nursalam. (2015). Manajemen Keperawatan Aplikasi dalam Praktik Keperawatan 
Profesional (edisi 5). jakarta: salemba medika.

Permenkes. (2017). Peraturan Menteri Kesehatan RI Nomor 11 tahun 2017 tentang keselamatan pasien.

Riesenberg, A, L., Leitzsch, J., \& Cunningham, M. (2010). Nursing handoffs: A systemic review of the literature : surprisingly little is known about what constitutes best practice. American Journal of Nursing, 110(4), 2434.

Rushton.H.C. (2010). Ethics of Nursing Shift Report.AACN:Advanced Critical care. Ethics in Critical Care, 21(4), 380-384.

Simamora, R. . (2014). Buku Ajar Manajemen Keperawatan. Jakarta: EGC.

Harsul,W, Syahrul S\& Majid, A. (2018). Penerapan Budaya Pelaporan Insiden Keselamatan Pasien Di Rumah Sakit Umum Daerah Tipe B Provinsi Sulawesi Selatan, 2(2), 119-126. 